Abstracta Iranica Abstracta Iranica

Revue bibliographique pour le domaine irano-aryen

Volume 23 | 2002

Comptes rendus des publications de $\mathbf{2 0 0 0}$

\title{
« Hallmarks of Humanism : Hygiene and Love of Homeland in Qajar Iran ». American historical Review, 105, (2000), pp. 1171-1203.
}

\section{Rudi Matthee}

\section{(2) OpenEdition}

Journals

Édition électronique

URL : http://journals.openedition.org/abstractairanica/35402

DOI : 10.4000/abstractairanica.35402

ISSN : 1961-960X

Éditeur :

CNRS (UMR 7528 Mondes iraniens et indiens), Éditions de l'IFRI

\section{Édition imprimée}

Date de publication : 15 mai 2002

ISSN : 0240-8910

Référence électronique

Rudi Matthee, « "Hallmarks of Humanism : Hygiene and Love of Homeland in Qajar Iran ». American historical Review, 105, (2000), pp. 1171-1203. », Abstracta Iranica [En ligne], Volume 23 | 2002, document 149, mis en ligne le 08 février 2010, consulté le 25 septembre 2020. URL : http:// journals.openedition.org/abstractairanica/35402 ; DOI : https://doi.org/10.4000/abstractairanica 35402

Ce document a été généré automatiquement le 25 septembre 2020.

Tous droits réservés 


\title{
« Hallmarks of Humanism : Hygiene and Love of Homeland in Qajar Iran ». American historical Review, 105, (2000), pp. 1171-1203.
}

\author{
Rudi Matthee
}

1 The leaders of late Qajar Iran, this sprawling, rather undisciplined article contends, embraced humanism and patriotic thinking in their quest for modernity. Humanism encompassed and served as a rallying cry for a host of themes and exhortations, ranging from hygiene and scientific learning to physical fitness, order and progress. Indeed, nationalism itself, hobb-e vatan, became inbricated in humanism, not simply as a territorial entity and an ideal but rather as a source of civilization and enlightenment. In her enthusiasm for the presumed novelty of the Qajar discourse, the author tends to overlook historical patterns of continuity. An example is the secular art of Qajar times, which is cited in support of a new humanism and presented as a new phenomenon in disregard of a secular tradition in Persian art that long precedes the Qajars. The real problem with the argument is that the author neither defines the operative term, humanism, insāniyyat, nor explores its antecedents. By making vague references to the Buyid period as exemplifying humanistic tendencies, and in mentioning the fact that Qajar humanism did not celebrate individualism, she creates the impression that the celebration of humanism was home-grown and did not owe anything to the transmission of Western, mostly French, social thought to the Middle East and its absorption by Qajar intellectuals. 
INDEX

Thèmes : 4.2.1. Safavides et Qâjârs

\section{AUTEURS}

RUDI MATTHEE

Université de Delaware (États-Unis) 